\title{
KUASA PEREMPUAN: PERANAN DAN KEDUDUKAN "BU NYAI" DALAM MEMIMPIN PONDOK PESANTREN DI KABUPATEN BANYUWANGI
}

\author{
Eny Puspita Ningrum ${ }^{1}$, Agus Mursidi ${ }^{2}$ \\ Fakultas Keguruan dan Ilmu Pendidikan, Universitas PGRI Banyuwangi ${ }^{1}$ \\ Email: Enypuspita2608@gmail.com \\ Email: agusmursidi78@gmail.com
}

\begin{abstract}
Pesantren atau lebih dikenal dengan istilah pondok pesantren dapat diartikan sebagai tempat atau komplek para santri untuk belajar atau mengaji ilmu pengetahuan agama kepada kyai atau guru ngaji, biasanya komplek itu berbentuk asrama atau kamar - kamar kecil dengan bangunan apa adanya yang menunjukkan kesederhanannya dan sampai saat ini pesantren tetap eksis menjadi lembaga pendidikan Islam di Indonesia. Mayoritas kepemimpinan pesantren didominasi oleh kyai. Dominasi tersebut menjadikan kyai sebagai sumber mutlak dari kekuasaan dan kewenangan dalam kehidupan di lingkungan pesantren. Sedangkan nyai hanya dijadikan pemimpin kedua yang tidak lebih hanya pemimpin di pondok pesantren putrid saja atau bahkan hanya sekedar pendamping kyai. Pemahaman kyai tentang superioritas laki-laki atas perempuan dalam segala bidang dana spek kehidupan semakin mempersempit ruang gerak nyai dalam mengembangkan pesantren. Berangkat dari permasalahan tersebut, peneliti mengadakan penelitian tentang peran dan kedudukan nyai dalam memimpin pesantren khususnya pesantren yang berada di kabupaten Banyuwangi. Penelitian ini menggunakan jenis penelitian kualitatif dengan menggunakan pendekatan grounded research yang dimana peneliti observasi langsung di lapangan. Penelitian ini terfokus pada 2 (dua) pesantren dengan karakter yang berbeda di Kabupaten Banyuwangi, yaitu pesantren Al-Kaustar Putri kecamatan Srono dan Pesantren Bustanul Makmur Kecamatan Genteng.
\end{abstract}

Kata kunci :Nyai, Kepemimpinan, Pondok Pesantren

\begin{abstract}
ABSTRACK
Pesantren or better known as boarding school can be interpreted as a place or complex of students to study or study religious knowledge to kyai or Koran teachers, usually the complex is in the form of dormitories or small rooms with buildings as they are that show their simplicity and to date pesantren still exist to be Islamic educational institutions in Indonesia.The majority of pesantren leadership is dominated by kyai. Dominationmaking kyai an absolute source of power and authority in the life of pesantren. While Nyai only used as a second leader who is no more just a leader in boarding school girls only or even just a kyai companion. The kyai's understanding of
\end{abstract}


male superiority over women in all areas and aspects of life further narrows the space of his movement in developing pesantren. Departing from these problems, researchers conduct research onthe role and position of nyai in leading the pesantren especially pesantren located in Banyuwangi district. This research uses a qualitative research type using a grounded research approach in which observers are directly in the field. This study focused on 2 (two) pesantren with different characters in Banyuwangi Regency, namely Al-KaustarPutri boarding school in Srono sub-district and BustanulMakmur Islamic boarding school in Genteng District.

Keywords: Nyai, Leadership, PondokPesantren

\section{Pendahuluan}

Agama masih sering dijadikan dalih sebagian orang untuk mewujudkan ketimpangan gender. Asumsi bahwa wanita adalah mahluk yang lemah, cengeng, dan mempunyai standart akal di bawah laki-laki sudah mengkristal dalam benak pemahaman mereka. Perempuan dikondisikan sedemikian rupa supaya mereka menganggap dirinya tidak layak disejajarkan dengan laki-laki. Lebih naif lagi, jika ketimpangan tersebut justru tumbuh subur dan mengakar di lembaga pendidikan seperti pesantren1.

Secara umum pesantren dipahami secara sederhana sebagai lembaga pendidikan .yang mempunyai sistem asrama atau mondok serta sebuah lembaga pendidikan yang pada pengajaran ilmu ilmu keislaman, khususnya pengajaran kitab

${ }^{l}$ Noer Chalida, Disertasi Doktor: "Kepemimpinan Pada Pondok Pesantren” (Surabaya: UIN SUNAN AMPEL, 2014), 1.
- kitab kuning.Pesantren di Indonesia tidak hanya lembaga pendidikan semata tapi juga lembaga sosial kemasyarakatan yang memiliki karakteristik - karakteristik tersendiri.Untuk konteks Jawa misalnya, pesantren adalah sebuah perpaduan antara prinsip dan tradisi budaya local dengan tradisi keagamaan, yaitu Islam. ${ }^{2}$

Istilah pesantren menurut Wahid (dalam Faiqoh, 2003:143) "merupakan institusi pendidikan religio-tradisional Islam, yang memiliki akar sejarah bukan saja di Indonesia akan tetapi juga di Asia Tenggara walaupun dengan istilah yang bervariasi, di daerah Aceh misalnya pesantren biasa disebut rangkang atau dayah, di Jawa dan Madura diistilahkan dengan pondok pesantren, sedangkan untuk daerah Malaysia, Muangthai Selatan dan Filipina Selatan biasanya disebut dengan istilah

\footnotetext{
${ }^{2}$ Eka Srimulyani, "Nyai Dan Umi Dalam Tradisi Pesantren Di Jawa Dan Dayah Di Aceh".Jurnal Masyarakat dan budaya Vol. 11 No. 1, 2009,54.
} 
pondok". Dalam hal sistem kepemimpinan, tradisi yang berlaku secara umum dalam dunia pesantren biasanya adalah cenderung mengutamakan laki - laki, biasanya keturunan laki - laki akan lebih di perioritaskan menjadi pimpinan dalam suksesi yang berlangsung di pesantren di bandingkan keturunan kyai perempuan (Muhammad, 2002:71).

Pemimpin adalah seorang pribadi yang memiliki superioritas tertentu, sehingga dia memiliki kewibawaan dan kekuasaan untuk menggerakkan orang lain melakukan usaha bersama guna mencapai sasaran tertentu. Pemimpin karismatis memiliki kekuatan energy, daya-tarik dan perbawa yang luar biasa untuk mempengaruhi orang lain, sehingga ia mempunyai pengikut yang sangat besar jumlahnya dan pengawalpengawal yang bisa dipercaya. ${ }^{3}$

Kyai merupakan elemen yang paling esensial dari suatu pesantren.Seorang kyai biasanya adalah pendiri lembaga pendidikan pesantren atau keturunannya.Masyarakat pedesaan khususnya, memandang kyai sebagai orang yang sangat berwibawa, kharismatik.Oleh sebab itu, seorang kyai

\footnotetext{
${ }^{3}$ Dr. Kartini Kartono, Pemimpin dan Kepemimpinan:Apakah Kepemimpinan Abnormal Itu?(Jakarta: Rajawali Pers, 2013), 81.
}

sangat dihormati dan sekaligus disegani, bahkan masyarakat sangat tunduk pada perkataan kyai. ${ }^{4}$ Menurut Aboebakar Aceh (dalam Karel A. Steinbrink, 1974:109), Seseorang di sebut kyai apabila memiliki beberapa aspek :

1. Pengetahuan Islam

2. Kesalehan

3. Keturunan kyai

4. Memiliki sejumlah murid (santri)

5. Pengabdian diri kepada masyarakat

Peran kyai sangat besar untuk tumbuh berkembangnya pondok pesantren tersebut. Kyai adalah seorang figure sentral yang mempunyai power dan otoritas penuh dalam menentukan kebijakan - kebijakan untuk perkembangan dan keberlangsungan suatu pondok pesantren sehingga kiai sebagai penguasa baik dalam pengertian fisik maupun non fisik yang memiliki tanggung jawab dalam kemajuan pesantren (Agus Mursidi, 2016:92). Pesantren telah menjadi pusat pembelajaran dan dakwah.Sebagai lembaga pendidikan tertua di Indonesia, pesantren memainkan peran yang sangat penting dalam sejarah pendidikan.Sebelum sistem pendidikan modern diperkenalkan

\footnotetext{
${ }^{4}$ Drs. Sri Ana Handayani, dkk, "Kedudukan dan Peranan Nyai Di Pondok Pesantren Sumber Wringin" (Jember: Universitas Jember, 1994), 6.
} 
oleh Belanda, pondok pesantren adalah satusatunya sistem pendidikan yang ada di Indonesia.Pondok pesantren juga memainkan peran yang tidak tergantikan dalam penyebaran Islam di Indonesia. Pondok pesantren menyediakan media sosialisasi formal di mana keyakinan, norma, dan nilai - nilai Islam ditransmisikan serta ditanamankan melalui berbagai aktivitas pengajaran. Dengan kata lain pondok pesantren berfungsi juga sebagai pengembang ajaran Islam dan pemeliharaan ortodoksi (Turmudi, 2004:37). ${ }^{5}$

Menurut Drs. Sri Ana Handayani, keberadaan pesantren selalu dikaitkan dengan karisma seroang kyai yang memimpin sekaligus sebagai pengajarnya. Demikian juga jumlah santri yang menimba ilmu di pesantren bergantung pada kedalaman ilmu yang dikuasai oleh kyainya, sehinga penelitian - penelitian tentang pesantren dan dinamikanya lebih difokuskan pada figur kyai sebagai tokoh sentralnya.Pada kenyataannya dalam mengelola suatu pesantren dan menangani permasalahannya para santri, khususnya santri putri, peranan nyai baik itu istri kyai

\footnotetext{
${ }^{5}$ Muhyidin Zainul Arifin, "Peran Kepemimpinan Nyai Di Pondok Pesantren". SAINTEKBUD: Jurnal Sains dan Teknologi Vol. 7 No. 2, Oktober 2014, 27.
}

atau saudara perempuan kyai yang cukup berperan dalam kelangsungan dalam sebuah pondok pesantren belum banyak di ungkapkan. ${ }^{6}$

Nyai dalam lingkungan pondok pesantren memiliki peranan dan kedudukan yang tak kalah penting juga, selain kyai. Pada umumnya peranan nyai hanya dapat dirasakan di lingkungan pesantren saja.Untuk itu perlu adanya penelitian yang mendetail tentang figur seorang nyai agar peranan dan kedudukan nyai dapat diungkapkan secara khusus, sehingga merekapun (nyai) dapat dijadikan sebagai salah satu figur publik baik bagi santri wanita maupun masyarakat umum.Nyai sebagai tokoh agama sekaligus juga sebagai pembawa perubahan kearah transformasi budaya, khususnya tentang peranan wanita pada era pembangunan dewasa ini.Untuk itu peneliti tertarik sekali untuk meneliti tentang peran dan kedudukan nyai dalam memimpin pondok pesantren.

Sudah banyak para peneliti meneliti tentang lembaga pesantren sebagai pusat pendidikan, sosial, ekonomi dan kyainya. Penelitian yang dilakukan lebih banyak

\footnotetext{
${ }^{6}$ Drs. Sri Ana Handayani, dkk, "Kedudukan dan Peranan Nyai Di Pondok Pesantren Sumber Wringin"(Jember: Universitas Jember, 1994), 6.
} 
menyoroti dari sisi ke esksistensian pesantren dan sosok karismatik seorang kyainya, dan hampir semua penelitian ditujukan pada kyai, sedangkan nyai sebagai pendamping kyai dalam menangani permasalahan pesantren, terutama tentang santri putri, selama ini belum ada yang meneliti secara spesifik. Padahal pada kenyataannya keberadaan nyai dalam membina santri dan mengembangkan pesantren sangatlah besar, karena nyai juga berperan penting dalam membina dan mengembangkan pesantren.

Sampai saat ini tulisan mengenai tentang pejuang wanita sudah ada seperti Tjut Nya Din, Nyi Ageng Serang, sebagai tokoh pejuang wanita pada masa Kolonial Belanda.Akan tetapi tulisan khusus tentang nyai sebagai tokoh karismatik selain kyai belum pernah diceritakan secara mendetail.Ada asumsi bahwa adanya sebuah budaya tradisional patriarkhis di pesantren yang menyebabkan peran nyai tidak terlalu menonjol.

Di kabupaten Banyuwangi sendiri terdapat 100 pondok pesantren, untuk sistem pembelajaran di pondok pesantren dibagi menjadi 2 (dua) yaitu modern dan salaf.Secara sederhana definisi pesantren salaf adalah sebuah pesantren yang menganut sistem tradisional yang di mana didalamnya mengajarkan ilmu-ilmu agama, dan untuk pengertian dari pondok pesantren modern sendiri yaitu pengajaran didalam pondok pesantren modern yang diajarkan tidak hanya ilmu-ilmu agama tetapi juga diajarkan ilmu-ilmu umum.Ciri khas dari pondok pesantren modern yaitu menekankan santri-santrinya dalam penguasaan bahasa asing yang digunakan dalam kegiatan sehari-hari, sedangkan ciri khas dari pondok pesantren salaf adalah lebih menekankan dalam penguasaan kitab kuning.

Di kabupaten Banyuwangi sistem pembelajarannya di pondok pesantren sudah banyak yang kombinasi yaitu salaf dan modern.Dari 100 pondok pesantren yang ada di kabupaten Banyuwangi peneliti mengambil 2 (dua) pondok pesantren yang di mana kedua pondok pesantren tersebut memiliki sistem pembelajaran yang berbeda. Pondok pesantren Al-Kautsar Putri Srono merupakan pondok pesantren dengan menerapkan sistem pembelajarannya modern kombinasi salaf karena santri dalam pondok tersebut kesehariannya menggunakan bahasa asing yaitu Arab dan Inggris, berbeda dengan pondok pesantren Bustanul Makmur Genteng, pondok tersebut menerapkan sistem pembelajaran salaf. Dan 
di kabupaten Banyuwangi masih banyak anggapan bahwa keberhasilan pondok pesantren karena adanya peran penting dalam kepemimpinan Kyai mengasuh pondok pesantren, padahal di belakang sosok Kyai terdapat istri Kyai (Bu Nyai) yang ikut berperan dalam mengembangkan pondok pesantren putri. Dari paparan di atas, peneliti merasa bahwa cukup penting untuk meneliti bagaimanakah kiprah dan peran $\mathrm{Bu}$ Nyai dalam memimpin pondok pesantren.Berangkat dari uraian di atas, maka terciptalah judul skipsi sebagai berikut."Kuasa Perempuan : Peran Dan Kedudukan “Bu Nyai” Dalam Memimpin Pondok Pesantren"

\section{Kajian Literatur dan pengembangan}

\section{Hipotesis}

\section{Pengertian Gender}

Kata "gender" dapat diartikan sebagai perbedaan peran, fungsi, status dan tanggungjawab pada laki-laki dan perempuan sebagai hasil dari bentukan (kontruksi) sosial budaya yang tertanam lewat proses sosialisasi dari satu generasi ke

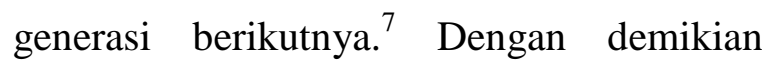
gender adalah bentuk kesepakatan dari

\footnotetext{
${ }^{7}$ Herien Puspiwati, “Konsep, Teori dan Analisis Gender”'(Bogor: Institut Pertanian Bogor, 2013), 1
}

manusia yang tidak ada kaitannya dengan bawaan lahir (kodrat).

Gender tercipta melalui proses sosial budaya yang panjang dalam suatu lingkup masyarakat tertentu, sehingga dapat berbeda dari tempat ke tempat lainnya (Dede William, 2006:3) Gender adalah perbedaan antara laki-laki dan perempuan yang dibangun secara sosial dan kultural yang berkaitan dengan peran, perilaku, dan sifat yang dianggap layak bagi laki-laki dan perempuan yang dapat dipertukarkan.

Islam tidak membedakan antara hak dan kewajiban yang ada pada anatomi manusia, hak dan kewajiban itu selalu sama di mata Islam bagi kedua anatomi yang berbeda tersebut. Islam mengedepankan konsep keadilan bagi siapapun dan untuk siapapun tanpa melihat jenis kelamin mereka.Islam adalah agama yang telah membebaskan belenggu tirani perbudakan, persamaan hak dan tidak pernah mengedepankan dan menonjolkan salah satu komunitas anatomi saja.Islam hadir sebagai agama yang menyebarkan kasih sayang bagi siapa saja. ${ }^{8}$

\section{Tipologi Pesantren}

\footnotetext{
${ }^{8}$ Mansour Fakih, dkk, "Membincang Feminisme Diskursus Gender Perspektif Islam" (Cet. III; Surabaya: Risalah Gusti, 2006), 11
} 
Secara etimologi, "pesantren" berasal dari pe-santri-an yang berarti tempat santri, asrama tempat santri belajar agama atau pondok.Dikatakan pula, pesantren berasal dari kata santri, yaitu seorang yang belajar dari agama Islam, dengan demikian pesantren mempunyai arti tempat orang berkumpul untuk belajar agama Islam (Zamakhsyari Dhofier. 1983:18). Sementara itu, secara terminologis, pondok pesantren merupakan institusi sosial keagamaan yang menjadi wahana pendidikan bagi umat Islam yang mendalami ilmu - ilmu keagamaan.Pondok pesantren dalam terminology keagamaan merupakan institusi pendidikan Islam, namun demikian pesantren memiliki modalitas sosial yang icon sosial yang memiliki pranata sosial di masyarakat. Hal ini karena pondok pesantren memiliki modalitas sosial yang khas, yaitu : ketokohan kyai, santri, independent dan mandiri, dan jaringan sosial yang kuat antar alumni pondok pesantren. ${ }^{9}$

Pengertian pondok pesantren menurut para ahli cukup banyak. Beberapa ahli tersebut adalah :

${ }^{9}$ Ali Maksum, "Model Pendidikan Toleransi di Pesantren Modern dan Salaf". Jurnal Pendidikan Agama Islam Vol. 3 No. 1, Mei 2015, 85-108
1. Dhofier (1994: 84) mendefinisikan bahwa pondok pesantren adalah lembaga pendidikan tradisional Islam untuk mempelajari, memahami, menghayati dan mengamalkan ajaran Islam dengan menekankan pentingnya moral keagamaan sebagai pedoman perilaku sehari-hari.

2. Team Penulis Departemen Agama (2003: 3) dalam buku Pola Pembelajaran Pesantren mendefinisikan bahwa pondok pesantren adalah pendidikan dan pengajaran Islam di mana di dalamnya terjadi interaksi antara kyai dan ustdaz sebagai guru dan para santri sebagai murid dengan mengambil tempat di masjid atau di halaman - halaman asrama (pondok) untuk mengkaji dan membahas buku - buku teks keagamaan karya ulama masa lalu. Dengan demikian, unsur terpenting bagi pesantren bagi pesantren adalah adanya kyai, para santri, masjid, tempat tinggal (pondok) serta buku buku (kitab kuning).

Dari berbagai pengertian diatas, dapat disimpulkan bahwa pesantren merupakan suatu lembaga pendidikan Islam tradisional yang di mana mempelajari ilmu - ilmu agama dengan menggunakan kitab - kitab kuning.

Para ahli pendidikan, mengklasifikasi jenis pesantren ke dalam dua tipologi; yakni 
pesantren modern, yang sudah banyak mengadopsi sistem pendidikan sekolah modern Barat dan pesantren salaf, yang berorientasi pada pelestarian tradisi dengan sistem pendidikan tradisional.

Pertama, Pondok pesantren modern, merupakan pengembangan tipe pesantren karena orientasi belajarnya cenderung mengadopsi seluruh sistem belajar secara klasik dan meninggalkan sistem belajar tradisional.Penerapan sistem belajar modern ini terutama nampak pada penggunaan kelas- kelas belajar baik dalam bentuk madrasah maupun sekolah.Kurikulum yang dipakai adalah kurikulum sekolah atau madrasah yang berlaku secara nasional.Santrinya ada yang menetap ada yang tersebar di sekitar desa lokasi pesantren. Kedudukan para kyai sebagai koordinator pelaksana proses belajar mengajar dan sebagai pengajar langsung di kelas. Perbedaannya dengan sekolah dan madrasah terletak pada porsi pendidikan agama dan bahasa Arab lebih menonjol sebagai kurikulum local (Maksum, 2015: $85-108) .{ }^{10}$

${ }^{10}$ Ali Maksum, "Model Pendidikan Toleransi di Pesantren Modern dan Salaf". Jurnal Pendidikan Agama Islam Vol. 3 No. 1, Mei 2015, 85-108
Kedua, pondok pesantren yang dulunya merupakan sebuah kelompok belajar dengan seorang kyai sebagai pembimbing yang pengajarannya dipusatkan di masjid dan semata-mata mengajarkan ilmu-ilmu agama melalui literature tradisional berupa kitab-kitab klasik atau kitab kuning dengan proses belajar mengajarnya menggunakan struktur dan metode tradisional pula, yaitu: sorongan, bondongan, wetonan, hafalan, muzarokah tanpa mengenal metode pengajaran lainnya, hal tersebut sangat khas sekali dengan ciriciri model pendidikan pondok pesantren yang dikategorikan sebagai pondok pesantren salafi (Stiawan dan Tohirin, 2015: 194-195). ${ }^{11}$

\section{Nyai dan Peranan Nyai}

Nyai merupakan tokoh-tokoh sentral di pondok pesantren.Nyai memiliki peran yang subtansional dalam mensosialisasikan konsep dan ajaran agama di pesantren.

Kepemimpinan nyai yang berprinsip kesederhanaan dalam konsep pemberian pelayanan seperti dalam sabda Nabi SAW: "Ra'is al-qaum khadamahum", yang artinya

\footnotetext{
${ }^{11}$ Kelik Stiawan dan M. Thohirin, "Format Pendidikan Pondok Pesantren Salafi dalam Arus Perubahan Sosial di Kota Magelang”. Fakultas Agama Islam Universitas Muhammadiyah Magelang Vol. X No. 2, Desember 2015, 194-195
} 
pemimpin suatu kaum adalah memberikan layanan bagi orang yang dipimpinnya (Arifin dan Slamet, 2010: 46). Ini menunjukkan bahwa peran nyai sebagai pemimpin dalam pondok pesantren harus mampu memberikan pelayanan terhadap seluruh komponen yang ada.

\section{Peran dan Posisi Perempuan dalam Perspektif Hukum Islam}

Berbicara mengenai kedudukan ${ }^{12}$ dan hak wanita $^{13}$ dalam Islam, mengantarkan kita untuk terlebih dahulu melihat pandangan AlQur'an tentang asal kejadian perempuan. Dalam hal ini, salah satu ayat yang dapat diangkat adalah firman Allah:

"Wahai seluruh manusia, sesungguhnya kami telah menciptakan kamu (terdiri) dari laki-laki dan perempuan dan kami jadikan kamu berbangsa-bangsa dan bersuku-suku agar kamu saling mengenal.Sesungguhnya

\footnotetext{
${ }^{12}$ Kedudukan perempuan dan laki-laki dalam berumah tangga adalah setara dalam Quran Surat Al Baqarah ayat 187 menyebutkan (Mereka itu adalah pakaian bagimu dan kamu pun pakaian bagi mereka) oleh karena itu kedudukan suami istreri harus saling melengkapi kekurang satu sama lain agar tercipta konsep musawwa (kemitraasejajaran) atau hubungan yang setara.

${ }^{13}$ Ada beberapa hak wanita yang disebutkan dalam AlQuran, diantaranya hak untuk memperoleh perlindungan yang wajar (QS.An-Nisa: 34) hak untuk memperoleh nafkah (QS. Ath -Thalaaq: 6), Hak untuk memperoleh bagian harta warisan (QS. An-nisa: 7) dan hak untuk berusaha dan memperoleh hasil usahanya (QS. An-Nahal: 97) dan hak memilih pasangan hidup (HR AhmadIbnu Majab) dikutip dari buku HAM dalam perspektif Islam, Salemba Diniyah, 2003 hlm. 55-58.
}

yang paling mulia di antara kamu adalah yang paling bertakwa".(Al-Hujurat ayat 13).

Ayat ini berbicara tentang asal kejadian manusia dari seorang laki-laki dan perempuan, sekaligus berbicara tentang kemuliaan manusia baik laki-laki maupun perempuan yang dasar kemuliaannya bukan keturunan, suku, atau jenis kelamin, tetapi ketakwaan kepada Allah SWT.Secara tegas dapat dikatakan bahwa perempuan dalam pandangan Al-Qur'an memiliki kedudukan terhormat. ${ }^{14}$

Kiprah wanita dalam sejarah menorehkan hasil yang gemilang.Wanita difahami telah memberikan andil yang besar dalam bidang intelektual klasik. ${ }^{15}$ Bahkan saat ini banyak wanita yang ikut andil dalam dunia politik, menjadi pemimpin di lembaga-lembaga seperti menjadi kepala sekolah, dan masih banyak lagi peran wanita.

Dengan demikian, dapat dikatakan bahwa Islam merupakan agama yang sangat menghormati dan menghargai perempuan dan laki-laki di hadapan Allah secara mutlak. Islam menghapus tradisi Jahiliyah

\footnotetext{
${ }^{14}$ Nalon Kurniawan. Jurnal Hak Asasi Perempuan dalam Perspektif Hukum dan Agama.

${ }^{15}$ Kasmawati “Gender dalam Perspektif Islam” Fakultas Tarbiyah dan Kependidikan UIN Alauddin Vol. 1 No. 1, Mei 2013, 56
} 
yang begitu diskriminatif terhadap perempuan, dalam Islam laki-laki dan perempuan dianggap sebagai makhluk Allah yang setara, bebas bertasarruf, bahkan satu sama lain saling melengkapi dan membutuhkan.

Penelitian tentang peran dan kedudukan bu nyai dalam memimpin pesantren ini menggunakan jenis penelitian kualitatif yang dilakukan untuk mencari titik temu antara bentuk teori dengan fenomena yang ada, dengan mengungkapkan respon atau tanggapan obyek penelitian.Dengan harapan dapat memberikan gambaran yang komperhensif terhadap obyek maupun subyek dalam penelitian yang dilakukan.Oleh karena itu digunakan pendekatan penelitian kualitatif dengan model model penelitian grounded research, karena peneliti langsung terjun ke lapangan untuk mengumpulkan data. Data yang diperoleh dianalisis menjadi fakta, dan dari fakta di interpretasikan menjadi konsep.

\section{Daftar Pustaka}

El-KhalieqyAbidah, 2001.Perempuan Berkalung Sorban. Yogyakarta: Arti Bumi Intaran.
Chalida Noer, 2014. Kepemimpinan Pada Pondok Pesantren. Surabaya: UIN SUNAN AMPEL.

Djaman Satori dan Aan Komariah. 2010.Metodologi Penelitian Kualitatif.Bandung: Alfabeta.

Eprijon Efendi, Eksistensi Wanita dalam Perspektif Islam. 2003.

Jurnal Universitas Sumatera Utara.

Mastuhu, Dinamika Sistem Pendidikan Pesantren, Jakarta: INIS, 1994.

Moleong, Metode Penelitian Kualitatif, Bandung : Rosdakarya, 2005.

Mukti Ali, Beberapa Persoalan Agama Dewasa Ini, Jakarta: Raja Wali.

Mursidi, Agus, 2016. Dominasi Kiai Dalam Pendidikan di pondok Pesantren Ihya'ulumiddin. Historia Volume 4, nomor 2. UMM Metro

Nanang Hasan Santoso,Tantangan mewujudkan kesetaraan Gender dalam Budaya Patriarkhi Vol.7 No.2, 2015.

Nasaruddin Umar, Pemberdayaan Perempuan, Jakarta: Logos Wacana Ilmu, 2000.

Nalon Kurniawan, Hak Asasi Perempuan dalam Perspektif Hukum dan Agama.

Nina Nurmila, Pengaruh Budaya Patriarki Terhadap Pemahaman Agama dan 
Pembentukan Budaya, Bandung: UIN

Sunan Gunung Djati, 2015.

Peter Connolly, Aneka Pendekatan Studi

Agama. Judul Asli: Approaches to The

Study ofRelegion, Yogyakarta: LKiS,

2012.

Sugiyono, Metode Penelitian Pendidikan

Pendekatan Kuantiatif, Kualitatif, Dan

$R \& D$, Bandung: Alfabeta, 2007.

Sutopo, H.B. Metodologi Penelitian Kualitatif : Dasar Teori dan Penerapannya dalam Penelitian, Surakarta: Pusat Penelitian Universitas Sebelas Maret, 2006.

Umar, Nasaruddin. Argumen Kesetaraan Gender Perspektif al-Qur'an, Jakarta: Paramadina, 2001.

U'un Qomariyah, Citra Perempuan Kuasa dalam Perspektif Kritik Sastra Feminis Novel Perembuan Berkalung Sorban Karya Abidah El-Kkalieqy.

Zaini, Wahid dkk, Memposisikan Kodrat: Perempuan dan perubahan dalam perspektif Islam, Cet. 1; Jakarta: Mizan, 1999.

Zamakhsyari Dhofier, Tradisi Pesantren cet. 2, Jakarta: LP3ES, 1994. 